\title{
Article \\ When Water Availability Is Low, Two Mediterranean Salvia Species Rely on Root Hydraulics
}

\author{
Elisa Abate, Maria Azzarà and Patrizia Trifilò * \\ Dipartimento di Scienze Chimiche, Biologiche, Farmaceutiche ed Ambientali, Università di Messina, \\ Viale Ferdinando Stagno d'Alcontres 31, 98166 Messina, Italy; elisa.abate@unime.it (E.A.); \\ mariaazzara960612@gmail.com (M.A.) \\ * Correspondence: ptrifilo@unime.it
}

Citation: Abate, E.; Azzarà, M.; Trifilò, P. When Water Availability Is Low, Two Mediterranean Salvia Species Rely on Root Hydraulics. Plants 2021, 10, 1888. https:// doi.org/10.3390/plants10091888

Academic Editors: Adriano Sofo and Arnon Dag

Received: 29 July 2021

Accepted: 8 September 2021

Published: 13 September 2021

Publisher's Note: MDPI stays neutral with regard to jurisdictional claims in published maps and institutional affiliations.

Copyright: (c) 2021 by the authors. Licensee MDPI, Basel, Switzerland. This article is an open access article distributed under the terms and conditions of the Creative Commons Attribution (CC BY) license (https:// creativecommons.org/licenses/by/ $4.0 /)$.

\begin{abstract}
Increase in severity and frequency of drought events is altering plant community composition, exposing biomes to a higher risk of biodiversity losses. This is exacerbated in the most fragile areas as Mediterranean biome. Thus, identifying plant traits for forecasting species with a high risk of drought-driven mortality is particularly urgent. In the present study, we investigated the drought resistance strategy of two Mediterranean native species: Salvia ceratophylloides Ard. (Sc) and Salvia officinalis L. (So) by considering the impact of drought-driven water content decline on plant hydraulics. Well-watered samples of $S c$ displayed higher leaf and stemsaturated water content and lower shoot biomass than So samples, but similar root biomass. In response to drought, $S c$ showed a conservative water use strategy, as the prompt stomatal closure and leaves shedding suggested. A drought-tolerant mechanism was confirmed in So samples. Nevertheless, Sc and So showed similar drought-driven plant hydraulic conductance $\left(K_{\text {plant }}\right)$ recover ability. Root hydraulic traits played a key role to reach this goal. Relative water content as well as loss of cell rehydration capability and membrane damages, especially of stem and root, were good proxies of drought-driven $\mathrm{K}_{\text {plant }}$ decline.
\end{abstract}

Keywords: climate change; Mediterranean species; membrane damages; plant hydraulic conductance; rehydration capacity; water content

\section{Introduction}

In the last decades, the increase in severity and frequency of drought events is exposing vegetation to a higher risk of drought-driven die-off [1-3]. According to climate projections, global warming is not expected to be homogeneous: higher increase in temperature and drought events have been forecasted for the Mediterranean region e.g., [4-6]. This, in turn, may lead to more relevant negative feedback on biodiversity richness of the Mediterranean biome, exacerbating the recorded ongoing vegetation pattern shifts [7-10] and increasing the extinction risk of endemic flora [11-13]. Mediterranean region shows high levels of plant diversity and endemism, as a result of different co-occurring factors [14,15]. The high numbers of endemic plant species are adapted to cope with warm and frequently long dry periods that typically occur in the Mediterranean biome. Thus, the Mediterranean biodiversity hotspot is coupled to different specific adaptive strategies for delaying and/or tolerating tissue dehydration i.e., [16-21]. However, increasing temperature and drought events may lead to exceeding the species-specific drought resistance threshold. Vegetation responses to ongoing climate change is a complex process involving the coordination of different and not well-understood physiological mechanisms. Plant hydraulics play a critical role in vegetation ability to cope with drought [22] and hydraulic failure is considered the major driver of vegetation die-off $[23,24]$. Nevertheless, many questions on plant hydraulics remain unresolved [22,25] and looking for a robust proxy for predicting plant die-back is urgent.

Changes in plant water content in response to drought have recently received a renewed attention [26]. Plant water status is linked to different key physiological mechanisms, 
including water transport and its regulation as well as carbon metabolism $[27,28]$. On this view, the relative water content (RWC) has been suggested as a simple indicator of plant mortality risk. However, the species-specific cell desiccation tolerance is still largely unknown. To the best of our knowledge, only few studies have investigated water content thresholds leading drought-induced mortality risk and it is unclear if a specific organ (leaf, stem, root) or whole plant water content can be an actual proxy of mortality risk. Rosner et al. [29] reported good correlations between stem RWC and the loss of hydraulic conductivity in certain tree species. However, in a most recent study, Mantova et al. [30] indicated that stem RWC is useful for predicting the loss of hydraulic conductivity in woody angiosperms but not in conifers.

In the present study, we reported the hydraulic performance, including changes in relative water content, of two native Mediterranean species, Salvia ceratophylloides Ard. (Sc), a perennial herbaceous species [31-33], and Salvia officinalis L. (So), a perennial evergreen subshrub [34], experiencing mild and severe drought events and then rewatering. In detail, we compared the drought resistance strategy of $S c$ versus $S o$ (i.e., a drought-tolerant species [35,36]) and the plant recovery ability of the two Salvia species in order to investigate if and how mild or severe leaf hydraulic impairment and/or loss in cell rehydration ability can affect the whole plant hydraulics. Similar whole-plant drought vulnerability is expected on species with similar leaf hydraulic safety [37-39]. However, to the best of our knowledge, no study has focused on-species showing a moderate succulence syndrome. Recently, Abate et al. reported higher leaf succulence in $S c$ versus So [40]. This, in turn, led to different RWC thresholds but similar leaf water potential and leaf water content for leaf dehydration vulnerability in the two Salvia species [40]. On this basis, we tested the impact of leaf hydraulic impairment on the whole plant drought vulnerability in $S c$ and So. Moreover, we checked: (i) possible relations between leaf, stem and root drought-driven water content and/or loss in cell rehydration ability and plant hydraulics of the two Salvia species in order to test possible tool(s) for monitoring the plant die-back and, then, for predicting the drought-driven risk of mortality; (ii) if hydraulic traits and/or drought resistance mechanism of $S c$ may expose this species to potentially higher risk of extinction under predicted climate change scenario. S. ceratophylloides is a rare endemic perennial herbaceous species of southern Italy [31]. Until 2008, such a species had been considered "extinct in the wild" but most recent studies documented the presence of natural populations in its native area (i.e., Calabria, Italy), suggesting that the vulnerability of $S$. cerathophylloides has been likely induced by anthropogenic causes (as an improper use of the soil) more than an unsuited species-specific water use strategy $[32,33]$.

\section{Results}

S. ceratophylloides and S. officinalis differed strongly in biomass and structural traits (Table 1). So showed higher shoot biomass compared to Sc. Significantly higher values of number of leaves per plant (about 165 versus 50), whole plant leaf area (2800 versus $800 \mathrm{~cm}^{2}$ ), leaves dry weight (13 versus $2 \mathrm{~g}$ ), and stem dry weight (1.1 versus $0.3 \mathrm{~g}$ ) were recorded in So versus Sc. Moreover, a different shoot biomass allocation was recorded: $S c$ showed a statistically significant two-fold higher stem/leaf ratio than So (Table 1). The two study species showed similar root dry mass (i.e., about $1.3 \mathrm{~g}$ ) but a 3-times higher root/shoot ratio value was recorded in Sc compared to So plants. Sc showed a higher leaf and stem-saturated water content (SWC) values than So. By contrast, not statistically significant different values of root SWC were recorded in the two species. 
Table 1. Mean values \pm SD of structural and biomass data and water storage traits as measured in well-watered samples of $S$. ceratophylloides and S. officinalis plants $(n=10)$. Differences between species were statistically analyzed and corresponding $p$ values are reported.

\begin{tabular}{cccc}
\hline Parameters & S. ceratophylloides & S. officinalis & $p$ Value \\
\hline & Structural and biomass data & & \\
N leaves/plant & $47.7 \pm 7.7$ & $164.7 \pm 59.3$ & $<\mathbf{0 . 0 0 1}$ \\
A $_{\mathrm{L}}\left(\mathrm{cm}^{2}\right)$ & $776 \pm 80$ & $2788 \pm 976$ & $<\mathbf{0 . 0 0 1}$ \\
LDMC & $0.16 \pm 0.01$ & $0.25 \pm 0.03$ & $<\mathbf{0 . 0 0 1}$ \\
DW leaves, & $2.2 \pm 0.9$ & $12.7 \pm 1.9$ & $<\mathbf{0 . 0 0 1}$ \\
N shoots/plant & $2.4 \pm 0.5$ & $2.5 \pm 1.3$ & 0.411 \\
DW stem, g & $0.3 \pm 0.1$ & $1.1 \pm 0.2$ & $<\mathbf{0 . 0 0 1}$ \\
SDMC & $0.22 \pm 0.03$ & $0.31 \pm 0.03$ & $<\mathbf{0 . 0 0 1}$ \\
Stem/leaf ratio & $1.78 \pm 0.95$ & $0.95 \pm 0.02$ & $\mathbf{0 . 0 0 7}$ \\
DW root, g & $1.1 \pm 0.4$ & $1.4 \pm 0.4$ & 0.104 \\
RDMC & $0.14 \pm 0.03$ & $0.18 \pm 0.01$ & $\mathbf{0 . 0 0 4}$ \\
Root/shoot ratio & $2.2 \pm 0.9$ & $0.6 \pm 0.3$ & $<\mathbf{0 . 0 0 1}$ \\
\hline & Water storage traits & $2.7 \pm 0.3$ & \\
SWC $_{\text {leaf }}$ g g $^{-1}$ & $4.8 \pm 0.4$ & $2.4 \pm 0.6$ & $<\mathbf{0 . 0 0 1}$ \\
SWC $_{\text {stem }}$ g g $^{-1}$ & $3.3 \pm 0.6$ & $4.4 \pm 0.5$ & $<\mathbf{0 . 0 1}$ \\
SWC $_{\text {root }}$ g g $^{-1}$ & $5.2 \pm 1.4$ & 0.061
\end{tabular}

$\mathrm{N}$ leaves/plant: number of leaves per plant; $A_{L}$ : whole plant leaf area; LDMC: leaf dry mass content; DW leaves: leaves dry weight per plant; $\mathrm{N}$ shoots / plant: number of shoots per plant; DW stem: stems dry weight per plant; SDMC and RDMC: stem and root dry matter content, respectively; DW root: root dry weight; Stem/leaf ratio and Root/shoot ratio: stem/leaf dry weight ratio and root/shoot dry weight ratio; $\mathrm{SWC}_{\text {leaf }}, \mathrm{SWC}_{\text {stem }}$ and $\mathrm{SWC}_{\text {root }}$ leaf: stem and root saturated water content, respectively.

The higher biomass values recorded in $S o$ versus $S c$ was likely due to the result of higher photosynthesis rate $\left(A_{n}\right)$ and water use efficiency (WUE) values as recorded in well-watered samples of $S o$ versus $S c$ (Figure 1). In response to mild $\left(\mathrm{S}_{\mathrm{P} 50}\right)$ and severe $\left(\mathrm{S}_{\mathrm{P} 88}\right)$ drought events, strong decreases in stomatal conductance to water vapor $\left(\mathrm{g}_{\mathrm{L}}\right)$, transpiration rate $\left(E_{L}\right)$ and photosynthetic rate $\left(A_{n}\right)$ were recorded in the two study species. However, in response to mild water stress, higher values of gas exchange and WUE occurred in So versus Sc. Moreover, a different drought sensitivity of the two Salvia species was recorded. In response to water shortage, a prompt stomatal closure occurred in $S c$ but not in So (Figure S1). As a consequence, at $\mathrm{S}_{\mathrm{P} 50}$ (i.e., $\Psi_{\mathrm{L}} \sim-2 \mathrm{MPa}$ ), So showed $\mathrm{g}_{\mathrm{L}} \operatorname{loss}$ of about $70 \%$, while in Sc samples, cuticular conductance values were already recorded. $S_{P 50}$ treatment did not induce permanent damages in the two Salvia species. After a week of re-irrigation, $\mathrm{S}_{\mathrm{P} 50}$ samples showed all measured parameters statistically similar to values recorded before drought. By contrast, no full recovery of gas exchange and WUE was recorded after the applied severe water stress, despite the full recovery of the leaf water potential.

Applied drought treatments strongly affected the relative water content of leaf, stem and root samples of the two Salvia species (Figure 2). However, after the rewatering, a full recovery of root RWC values was recorded, including when a severe water stress was experimented by $S c$ and So samples. This recovery was coupled to new roots growth, as observed in both species (data not shown). A different behavior was observed in the stem and leaf samples of the two Salvia species, especially in response to severe drought treatment. Water stress inducing $50 \%$ loss of leaf hydraulic conductance $\left(\mathrm{K}_{\mathrm{L}}\right.$, i.e., $\left.\mathrm{S}_{\mathrm{P} 50}\right)$ did not affect the leaf and stem cell ability to recover water content in $S c$ and So samples and no permanent damage was recorded after rewatering in the two Salvia species. By contrast, experiencing about $88 \%$ loss of leaf hydraulic conductance (i.e., $\mathrm{S}_{\mathrm{P} 88}$ ), only a partial recovery of leaf RWC values in Sc as well as So samples was recorded. The inability to recover the leaf water content was likely induced by a residual $20 \%$ loss in cell rehydration capability, as recorded in the two species even after rewatering. However, leaf Sc samples were more severely affected by $\mathrm{S}_{\mathrm{P} 88}$ treatment. In accordance, $\mathrm{S}_{\mathrm{P} 88}$ leaf samples of $S c$ showed higher leaf cell membrane damages (i.e., REL 70\% versus $40 \%$, respectively) and higher percentage loss of cell rehydration capability (PLRC) values (i.e., $80 \%$ versus 
$20 \%$, respectively) compared to So $S_{\mathrm{P} 88}$ leaf samples. Moreover, So stem samples were not permanently affected by experiencing severe water stress. By contrast, in RecSP88 $S c$ stem samples, a residual $20 \%$ PLRC and REL values as high as about $35 \%$ were recorded.
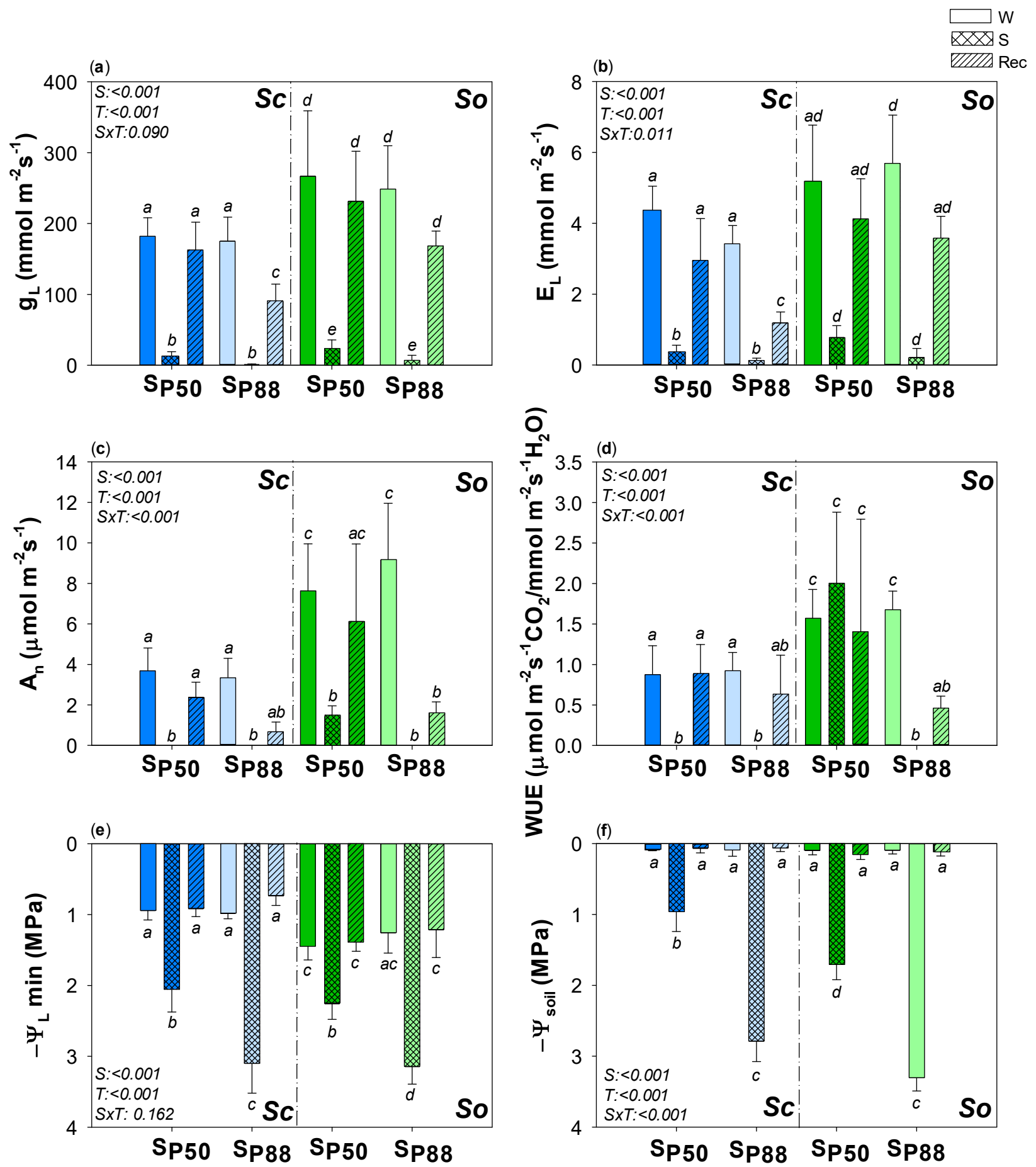

Figure 1. Effect of experimental treatments on gas exchange and water potential. Mean $\pm \operatorname{SD}(n=6)$ values of: (a) midday leaf conductance to water vapor, $\mathrm{g}_{\mathrm{L}} ;(\mathbf{b})$ transpiration rate, $\mathrm{E}_{\mathrm{L}},(\mathbf{c})$ photosynthetic rate, $\mathrm{A}_{\mathrm{n}}$, (d) water use efficiency, WUE, (e) leaf water potential, $\Psi_{\mathrm{L}}$ and (f) soil water potential, $\Psi_{\text {soil }}$ as recorded in well-watered (W, none pattern), water-stressed (S, slanting dash) and re-irrigated (Rec, mesh dash) plants of S. ceratophylloides (Sc, blue columns) and S. officinalis (So, green columns) submitted to two different water stress levels, i.e., $\mathrm{S}_{\mathrm{P} 50}$ and $\mathrm{S}_{\mathrm{P} 80}$ (for details, see the text). $p$ values as obtained by the two-way ANOVA analysis are reported. Different letters indicate statistically significant differences between groups. 

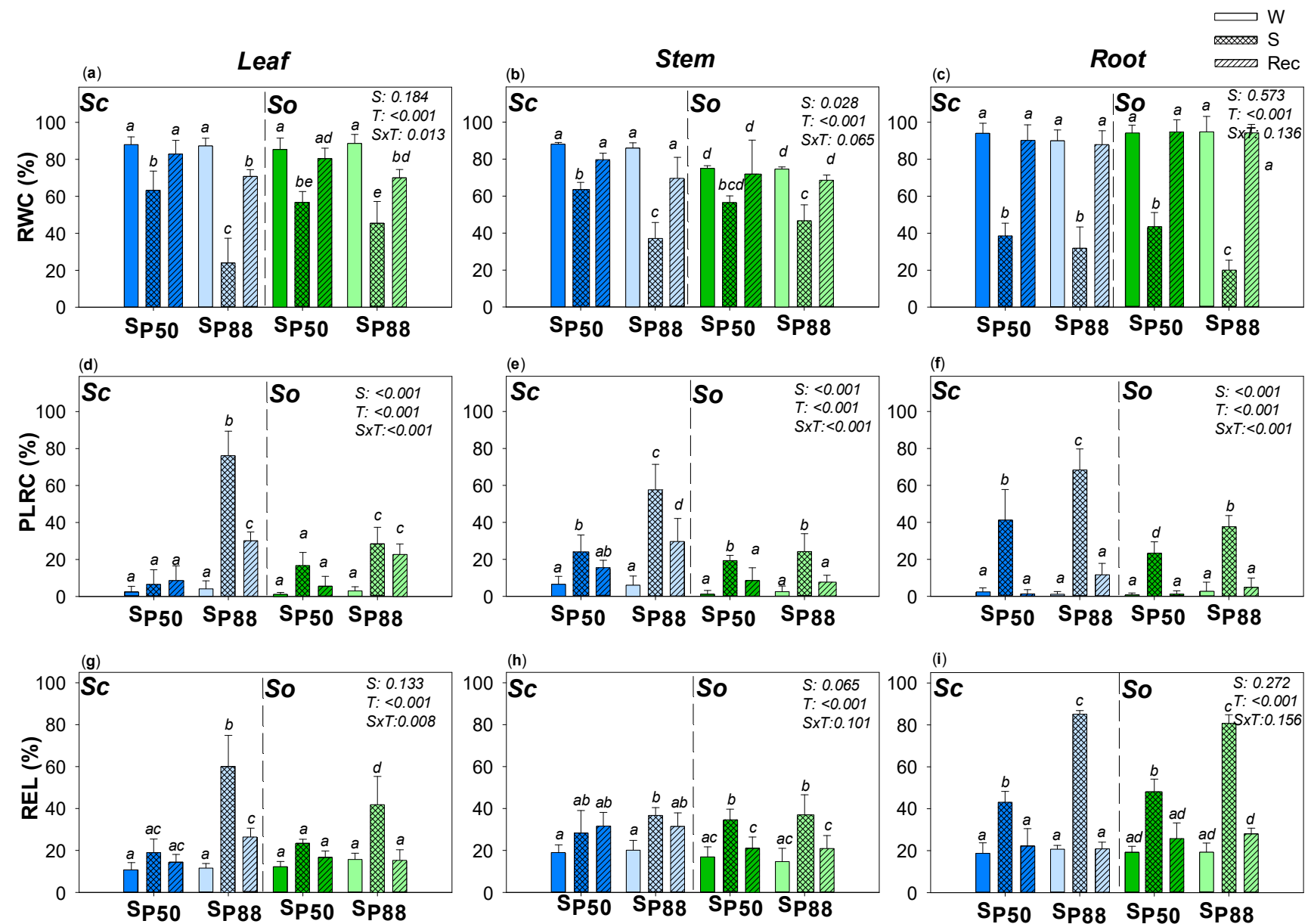

Figure 2. Effect of experimental treatments on water content and drought-driven damages. Mean $\pm \operatorname{SD}(n=5)$ values of relative water content (RWC); percentage loss of rehydration capability (PLRC) and relative electrolyte leakage (REL) as recorded in leaf $(\mathbf{a}, \mathbf{d}, \mathbf{g})$, stem $(\mathbf{b}, \mathbf{e}, \mathbf{h})$ and root $(\mathbf{c}, \mathbf{f}, \mathbf{i})$ samples of well-watered (W, none pattern), water-stressed (S, slanting dash) and re-irrigated (Rec, mesh dash) plants of $S$. ceratophylloides ( $S c$, blue columns) and S. officinalis (So, green columns) submitted to two different water stress levels, i.e., $S_{P 50}$ and $S_{P 80}$ (for details, see the text). $p$ values as obtained by the two-way ANOVA analysis are reported. Different letters indicate statistically significant differences between groups.

So and $S c$ well-watered samples showed similar plant hydraulic conductance $\left(\mathrm{K}_{\text {plant }}\right)$ values (Figure 3). Moreover, similar $K_{\text {plant }}$ values were recorded when the two Salvia species were submitted to the two drought treatments and then re-irrigated (Figure 3).

Robust correlations were recorded between $\mathrm{K}_{\text {plant }}$ and leaf, stem and root relative water content in the two Salvia species (Figures 4 and 5). Drought-driven $K_{\text {plant }}$ decline was clearly strongly related to the cell loss rehydration capability as well as to drought-driven cell membrane damages. RWC, PLRC and REL thresholds of $\mathrm{K}_{\text {plant }}$ impairment were similar among the three plant organs as well as between $S c$ and So (Figures 4 and 5, Table S1). Only leaf RWC value leading to $80 \%$ loss of $\mathrm{K}_{\text {plant }}$ was significantly lower in $S c$ versus $S o$, as well as no confidence intervals overlapping being recorded between $S c$ leaf versus $S o$ root REL value leading to $50 \%$ loss of $\mathrm{K}_{\text {plant }}$ (Figures 4 and 5, Table S1). Nevertheless, overall, in all three plant organs, RWC values as low as about $65 \%$ as well as PLRC values of about $15 \%$ led to $\mathrm{K}_{\text {plant }}$ loss of $50 \%$ in the two Salvia species. 


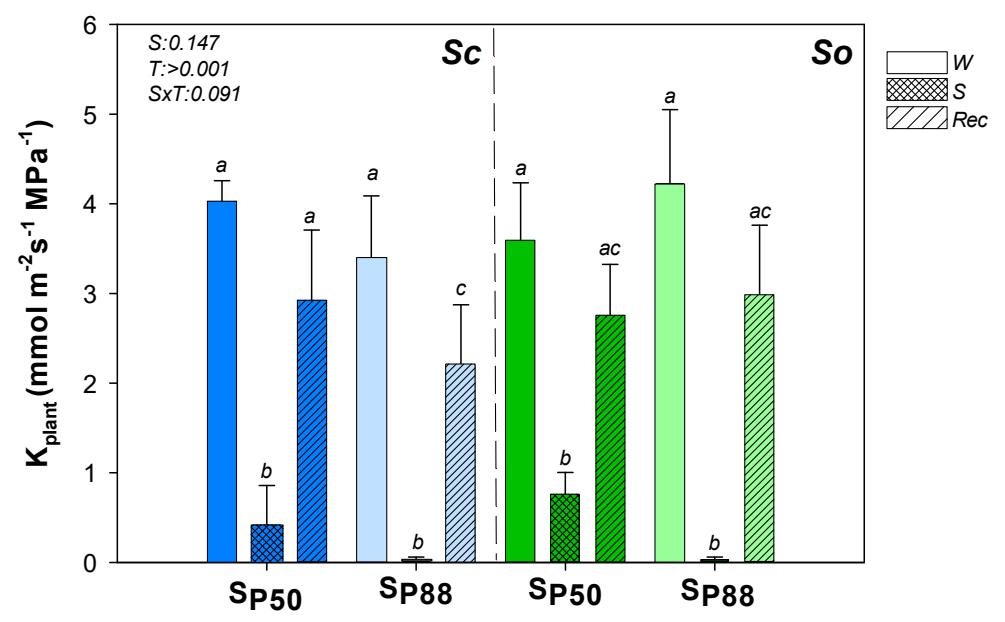

Figure 3. Effect of experimental treatments on plant hydraulic conductance. Mean $\pm \operatorname{SD}(n=6)$ values of plant hydraulic conductance $\left(\mathrm{K}_{\text {plant }}\right)$ as recorded in well-watered (W, none pattern), water-stressed (S, slanting dash) and re-irrigated (Rec, mesh dash) plants of S. ceratophylloides (Sc, blue columns) and

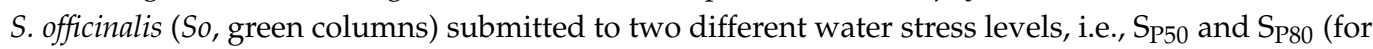
details, see the text). $p$ values as obtained by the two-way ANOVA analysis are reported. Different letters indicate statistically significant differences between groups.
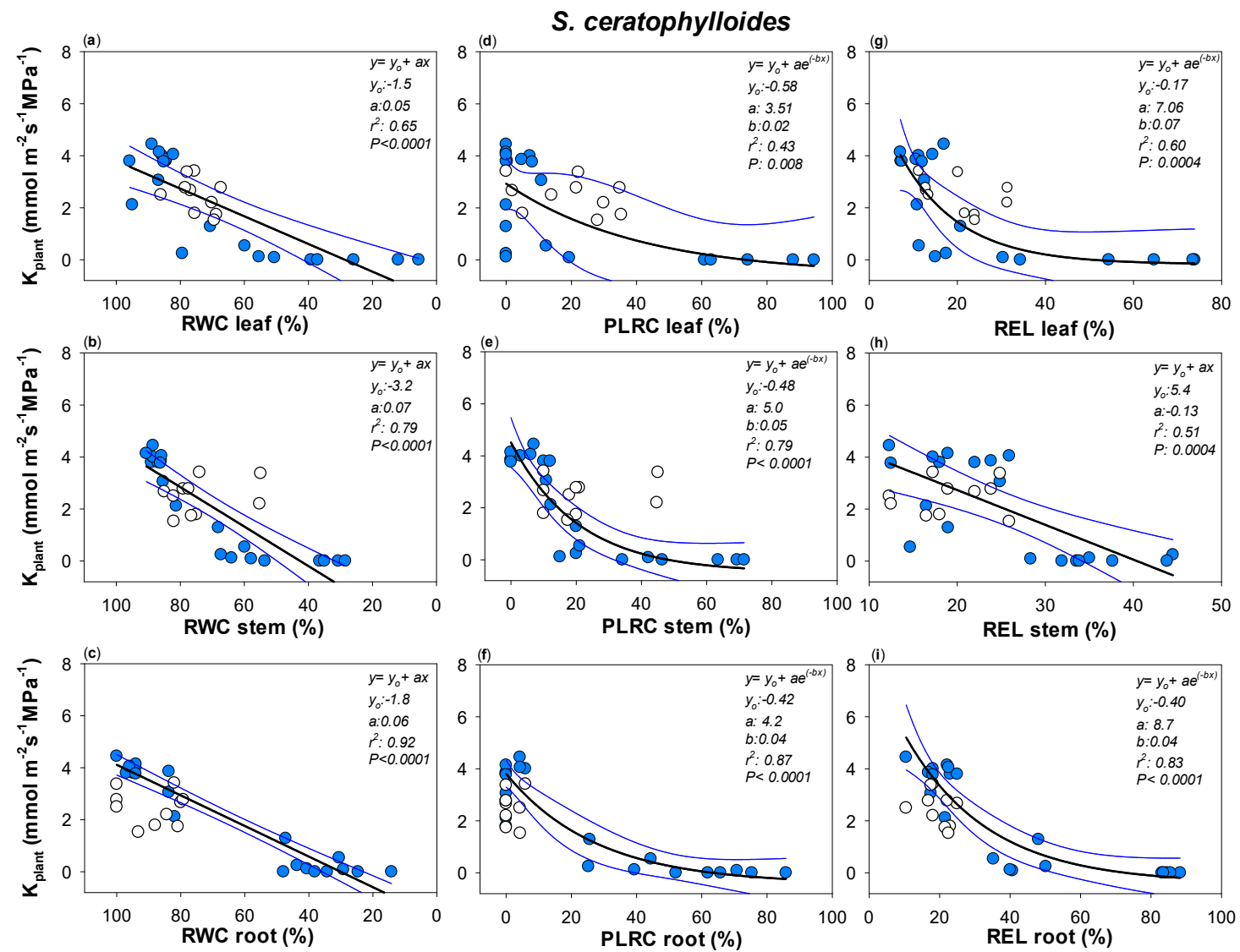

Figure 4. Relationships between plant hydraulic conductance $\left(\mathrm{K}_{\text {plant }}\right)$ and (a) leaf, (b) stem and (c) root relative water content (RWC leaf, RWC stem and RWC root, respectively), (d) leaf, (e) stem and (f) root percentage loss of leaf rehydration capacity (PLRC leaf, PLRC stem, PLRC root) and (g) leaf, (h) stem and (i) root relative electrolyte leakage (REL leaf, REL stem and REL root) as measured in S. ceratophylloides. Best fitted regression curves are designed by dark line. Confidence intervals are designed by blue lines. White symbols indicate data recorded in re-irrigated samples and not included in the regression. Regression equation, coefficient values, correlation coefficients $\left(\mathrm{r}^{2}\right)$ and $p$ values are also reported. 

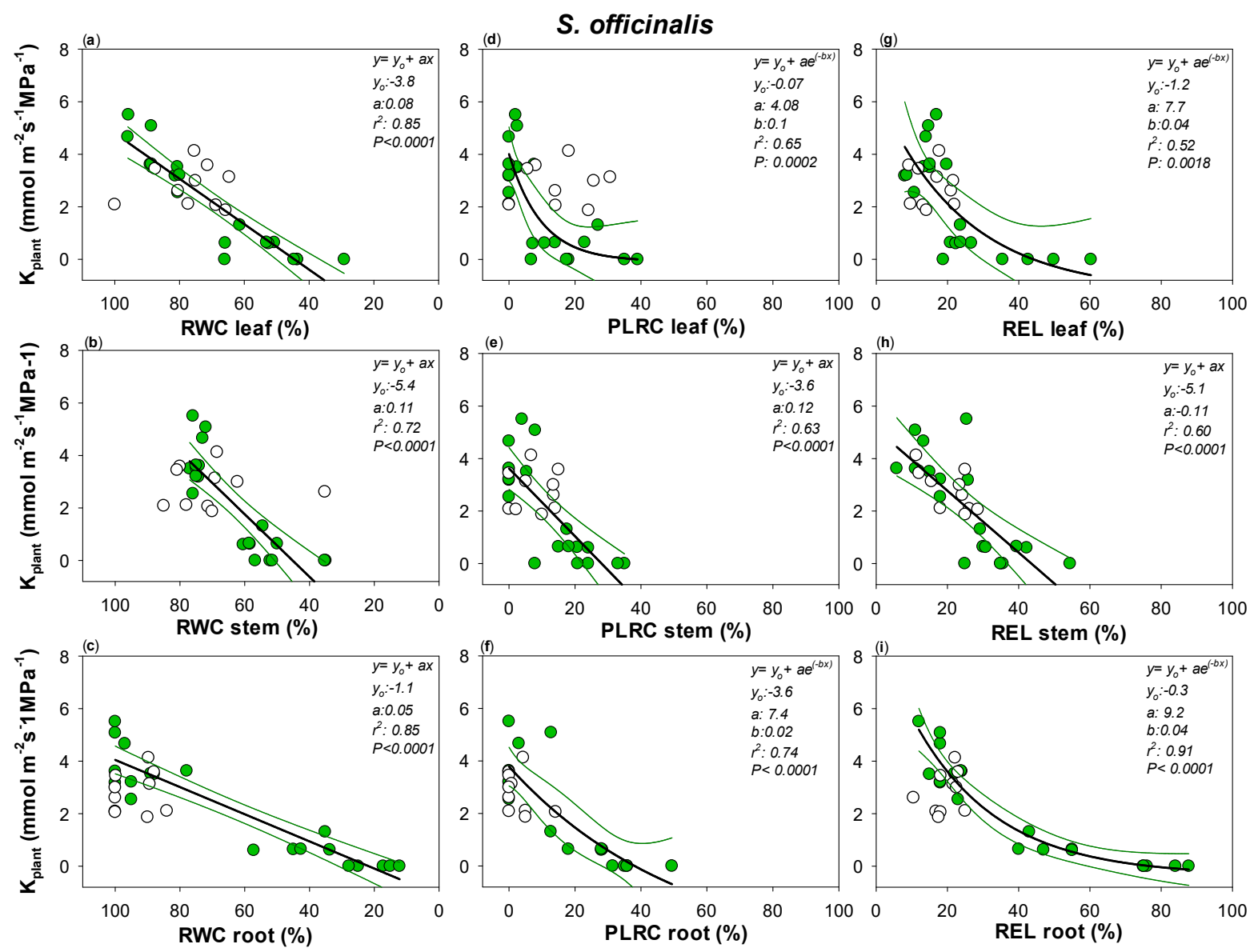

Figure 5. Relationships between plant hydraulic conductance $\left(K_{\text {plant }}\right)$ and (a) leaf, $(\mathbf{b})$ stem and (c) root relative water content (RWC leaf, RWC stem and RWC root, respectively), (d) leaf, (e) stem and (f) root percentage loss of leaf rehydration capacity (PLRC leaf, PLRC stem, PLRC root) and (g) leaf, (h) stem and (i) root relative electrolyte leakage (REL leaf, REL stem and REL root) as measured in S. officinalis. Best fitted regression curves are designed by dark line. Confidence intervals are designed by green lines. White symbols indicate data recorded in re-irrigated samples and not included in the regression. Regression equation, coefficient values, correlation coefficients $\left(\mathrm{r}^{2}\right)$ and $p$ values are also reported.

It can be noted that large confidence intervals were recorded between leaf PLRC and REL values and the corresponding plant hydraulic conductance declines. By contrast, most robust correlations were recorded between $\mathrm{K}_{\text {plant }}$ and stem and root samples.

\section{Discussion}

S. ceratophylloides and S. officinalis exhibited different resistance mechanisms for coping with drought but a similar plant hydraulics recovery ability, especially in response to severe drought. In detail, recovery from mild water stress led to similar water content values in the three plant organs of the two Salvia species. However, different gas exchange and water use efficiency values occurred in $S c$ versus $S$. By contrast, experiencing about $80 \%$ of $\mathrm{K}_{\mathrm{L}}$ loss caused different residual leaf and stem cell damages in $S c$ versus So samples but similar impact on gas exchange. Nevertheless, a similar $\mathrm{K}_{\text {plant }}$ recovery was recorded in $S c$ and So in response to the two drought recovery treatments and no plant death was recorded after a month by the end of the experimental period (personal observation). Hydraulic recovery was obtained by new roots production and, then, renewed root functioning in Sc and So samples. This avoided permanent loss in root cell rehydration capability and cell membrane damages in fine roots (i.e., site of water and nutrient uptake). Overall, these results strongly suggest that root hydraulics plays a key role in whole-plant recovery ability of the two Mediterranean native Salvia species. Moreover, our findings highlight that drought-driven changes in leaf RWC and PLRC values do not always provide proxy of plant 
hydraulic failure, especially when succulent and/or water saving species are considered. In accordance, likely as a consequence of relevant cell damages, a consistent leaf shedding in $S$. ceratophylloides $\mathrm{S}_{\mathrm{P} 88}$ samples occurred (Figure 6). Nevertheless, after a week of rewatering, new sprouting leaves were observed in $S c \operatorname{Rec}_{S P 88}$ samples (Figure 6). On this view, leaf hydraulic impairment weakly affected plant hydraulic conductance decline in Sc (i.e., a water saver species showing a moderate succulence syndrome). Drought resistance strategy shown by $S c$ may affect its survival under frequent and extreme drought events.

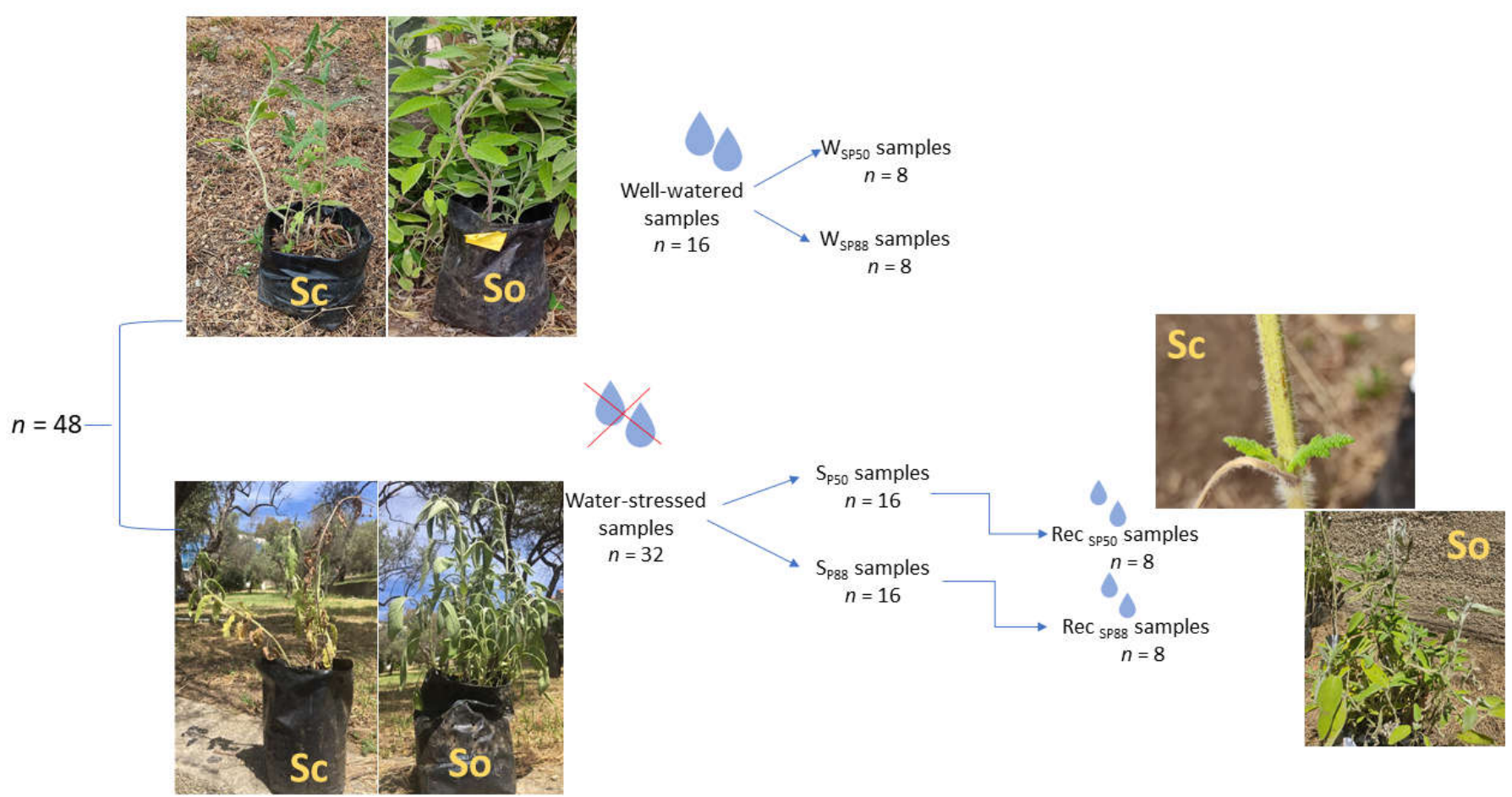

Figure 6. Experimental design: 48 potted samples of S. ceratophylloides (Sc) and S. officinalis (So) were divided into two groups: watered samples $(n=16)$ and water-stressed samples $(n=32)$. Watered samples $(\mathrm{W})$ were regularly irrigated at field capacity during the experimental period and measured, as control samples, at the same time as water-stressed samples (i.e., 8 samples for each drought treatment). Water-stressed samples were further divided into two groups subjected to a mild (i.e., $\mathrm{S}_{\mathrm{P} 50}$ samples, $\left.n=16\right)$ and a severe $\left(\mathrm{S}_{\mathrm{P} 88}, n=16\right)$ water-stress treatment, respectively. A subset of these samples $(n=8)$ was measured when the imposed water stress level was reached, while the other subset of drought-treated samples $(n=8)$ was re-irrigated at field capacity (i.e., Rec SP50 and Rec SP88 samples) and then measured.

\subsection{Two Different Drought Resistance Strategies but a Similar Root Hydraulics Recovery Ability}

S. ceratophylloides invested less in biomass accumulation than S. officinalis, as lower LDMC, SDMC and RDMC values suggested. This was likely the result of lower stomatal conductance, photosynthesis rate and WUE as recorded in well-watered Sc versus So samples. These findings, along with the different leaf and stem SWC values recorded in the two Salvia species, confirmed a more pronounced succulent syndrome in S. ceratophylloides than in S. officinalis [40]. Overall, our results lead to consider S. ceratophylloides a resourceconserving species. By contrast, $S$. officinalis exhibited a resource acquisitive strategy [41]. Well-watered samples of So showed higher $A_{n}$, WUE as well as leaf, stem and root dry matter content values than $S c$ plants. Moreover, So showed a lower stomatal conductance reduction in response to mild drought: this led to higher gas exchange than Sc. Thus, our data confirmed a drought-tolerant mechanism in So samples $[35,36]$. By contrast, a water-saving strategy was recorded in Sc. In response to mild stress, full stomatal closure was recorded in this species, and in response to severe stress, leaves shedding occurred. To avoid losses in carbon gain, species adapted to water shortage can increase their water-use efficiency (WUE) i.e., [42]. This strategy can be coupled to specific anatomical traits (as 
high vessel density and fibers and then high leaf mass per area) aimed at minimizing water loss i.e., [43]. In accordance, leaf mass area (LMA) increases along aridity gradients at a global scale [41]. However, $S c$ showed a lower LMA value than $S o$ [40] as well as a relevant reduction in WUE values in response to mild drought. Thus, the strategy adopted by $S c$ to cope with drought may explain the limited diffusion of this species in the Mediterranean region. The prompt stomatal closure, typically recorded in the water-saving species, as well as the inability to improve WUE under mild stress led to an unavoidable decrease in carbon uptake. In the long term, especially after several severe drought events, this reduction in carbon assimilation may limit the sustainability of plant metabolism and its ability to recover from drought. This, in turn, may increase the chance of plant die-back. On this view, water-saving strategy is actually less efficient than drought-tolerant mechanisms [44].

Nevertheless, similar plant hydraulic conductance declined, and mainly, similar hydraulic recovery ability in response to drought-re-irrigation treatment was recorded in the two Salvia species. In response to a mild drought, no permanent damages of $\mathrm{K}_{\mathrm{plant}}$ were recorded. Moreover, drought-driven relevant leaf hydraulic dysfunction (i.e., $\mathrm{K}_{\mathrm{L}}$ loss $\sim 88 / \%$ ) led to similar residual $\mathrm{K}_{\text {plant }}$ loss of about $40 \%$ in Sc and So. The recovery of the two Salvia species was obtained mainly by root hydraulics recovery. Sc and So root hydraulics did not remain negatively affected, including by a severe drought event. Root hydraulic conductance recovery can be obtained with the growth of new roots thus by-passing the irreversible and permanent drought-driven damages occurring at root level [45-49]. However, root hydraulics can be restored before growing new roots by renewing the permeability of damaged roots, as documented in succulent Agave and Opuntia [45,49]. Our results strongly confirm that a high root biomass allocation, as recorded in both species, plays a key role in coping drought [50-52], and highlight the urgency to fill gaps in our knowledge on the relevance of root hydraulics in regulating whole plant hydraulics, especially under drought [47,53-56]. Additional experiments aimed to investigate coupled physiological and morphological root traits, and especially their changes in response to drought, are needed to improve our lacking knowledge on this topic.

\subsection{Water Content and Loss in Rehydration Capability Actually Drive Plant Hydraulics}

Water content, but also loss of rehydration capability and cell membrane damages, were actually a proxy of the drought-driven plant hydraulic conductance decline in the two Salvia species. However, despite robust correlations occurring in all three organs, higher correlation values were recorded in root samples of the two Salvia species. Moreover, the recorded large confidence intervals in the relationships between the drought-driven leaf PLRC and REL increases and the corresponding $K_{\text {plant }}$ declines suggested a low reliability of these leaf parameters as indicator of plant hydraulic failure. Conversely, in water saving species, such as $S c$, leaf shedding occurs promptly to reduce water loss, and at the same time, can limit xylem embolism spread. This, in turn, avoids that hydraulic failure extends to the more carbon-expensive organs, according to the "hydraulic segmentation hypothesis" [57]. As a consequence, in this case, the leaf hydraulic failure may not necessarily lead to unavoidable plant hydraulic failure, but it may be the signal of the implementation of an adaptive strategy aimed to maintain adequate plant water content and/or tolerate substantial water losses and tissue dehydration. On this basis, this specie-specific droughtresistance strategy may overshadow link(s) between drought-driven plant decline and leaf hydraulics traits.

\section{Materials and Methods}

\subsection{Plant Material and Growth Conditions}

Experiments have been performed on 48 samples per species of S. ceratophylloides (Sc) and S. officinalis (So) plants. Seeds were planted in greenhouse trays in October 2019, after maintaining them immersed in water for $24 \mathrm{~h}$. A month from sprouting, each seedling was transferred to a 3.4 L-pot, filled with forest soil collected from Colli San Rizzo (Messina, Italy) and grown in a greenhouse until the beginning of May 2020. The greenhouse received 
natural light, with maximum daily values of photosynthetic photon flux density (PPFD) averaging $810 \pm 260 \mu \mathrm{mol} \mathrm{s}-1 \mathrm{~m}^{-2}$, air temperature ranging from $21 \pm 2{ }^{\circ} \mathrm{C}$ to $17 \pm 2{ }^{\circ} \mathrm{C}$ (day/night), and air relative humidity of $55 \pm 3 \%$.

In May 2020, the samples were transferred to a garden of the Department CHIBIOFARAM, University of Messina, Italy, and regularly irrigated at field capacity for a month. Then, in June 2020, Sc and So plants were randomly divided into two groups (Figure 6). One group $(n=16)$ was regularly irrigated at field capacity during the entire experimental period (i.e., watered samples, W). The second group (i.e., water-stressed samples, S, $n=32)$ was further divided into two groups $(n=16)$ submitted to two different levels of water stress (Figure 6). Specifically, water stress was induced by withdrawing irrigation until the two Salvia species reached the leaf water potential $\left(\Psi_{\mathrm{L}}\right)$ inducing about $50 \%$ (i.e., $\Psi_{\mathrm{L}} \sim-2.0 \mathrm{MPa}, S_{P 50}$ samples) and $88 \%$ (i.e., $\Psi_{\mathrm{L}} \sim-3.1 \mathrm{MPa}, \mathrm{S}_{\mathrm{P} 88}$ samples) loss of leaf hydraulic conductance, $\mathrm{K}_{\mathrm{L}}$, as recorded by some of us in a precedent study [40]. Then, a subset of $S_{P 50}(n=8)$ and $S_{\text {P88 }}$ samples $(n=8)$ was measured (see below) and the other subset of $S_{P 50}(n=8)$ and $S_{P 88}$ samples $(n=8)$, was re-irrigated and measured after 7 days (i.e., RecsP50 and RecsP8 samples, respectively).

During the experimental period, no rainy events occurred. The temperature ranged from 18 to $26^{\circ} \mathrm{C}$ and the mean relative humidity was $65 \pm 3.2 \%$ (weather station of Torre Faro, Messina, Italy).

\subsection{Gas Exchange and Water Status}

Preliminary measurements on plants of similar age and growth conditions of those used in this study showed that $S_{P 50}$ value was reached after 5-6 days and 3-4 days from withholding water in $S c$ and $S o$, respectively, while $S_{P 88}$ value was recorded after 10-11 days in $S c$ and after 7-8 days in So from suspending irrigation. To avoid defoliation, we monitored the leaf water potential (i.e., $\Psi_{\mathrm{L}}$ ) declines on two leaves per day, as collected from different plants, starting from the 4 th and 2nd day from withholding irrigation in $S_{\mathrm{P} 50}$ Sc and So samples, respectively. Similarly, $\Psi_{L}$ value of $S_{P 88}$ samples were measured starting from the 8th and 5th day from suspending irrigation in $S c$ and So, respectively. This experimental procedure led us to remove no more than 2 leaves per sample.

Leaf water potential was measured by a portable pressure chamber (3005 Plant Water Status Console, Soilmoisture Equipment Corp., Goleta, CA, USA).

$\Psi_{\mathrm{L}}$ as well as leaf conductance to water vapor $\left(\mathrm{g}_{\mathrm{L}}\right)$, transpiration rate $\left(\mathrm{E}_{\mathrm{L}}\right)$ and photosynthetic rate $\left(A_{n}\right)$ were measured at midday in $W, S$ and re-irrigated samples using a portable LCi Analyzer System (ADC Bioscientific Ltd., Herts, UK). The water use efficiency (WUE) of each measured plant was estimated by the ratio: $A_{n} / E_{L}$. At least six plants per species and per treatment were measured.

4.3. Estimating the Relative Water Content, Rehydration Capacity and Cell Membrane Integrity of Leaf, Stem and Root Samples Experiencing Drought-Recovery Treatment

Immediately after gas exchange and water status measurements and on the same W, S and Rec measured samples, the soil was gently removed from the root system and at least 2 samples of about $2 \mathrm{~cm}$-long root, stem samples, and 2 leaves per plant and treatment were collected for RWC, PLRC and REL measurements.

RWC was calculated as: $100 \times[(\mathrm{FW}-\mathrm{DW}) / \mathrm{DW}] /$ SWC and PLRC as: $100 \times 100-$ $[(\mathrm{TW}-\mathrm{DW}) / \mathrm{DW}] / \mathrm{SWC}$ where FW is the fresh weight (i.e., the sample weight as measured immediately after sampling), TW is the turgid weight (i.e., the sample weight as measured after maintaining the petiole or the whole stem and root sample immersed in deionized water for at least $8 \mathrm{~h}$ ), DW is the dry weight (i.e., the oven-dried sample weight) and SWC is the saturated water content (i.e., TW/DW, $\mathrm{g} \mathrm{g}^{-1}$ ) of sample at full turgor. Applied formula for estimating RWC allowed us to avoid mistakes as caused by cell loss rehydration ability, especially in low water status samples [40]. Cell membrane integrity was indirectly estimated by electrolyte leakage test measurements [58]. Leaf discs of about $0.5 \mathrm{~cm}^{2}$ as well as $2 \mathrm{~cm}$ long root and stem samples were cut with a razor blade and inserted into a test tube containing $8 \mathrm{~mL}$ of distilled water. Samples were stirred for $30 \mathrm{~min}$ at room 
temperature; then, the initial electrical conductivity of the solution $\left(\mathrm{EC}_{\mathrm{i}}\right)$ was recorded by a conductivity meter (Cond 5, XS instruments, Carpi, Italy). Samples were then subjected to three freeze-thaw cycles $\left(-20^{\circ} \mathrm{C},+20^{\circ} \mathrm{C}\right)$ to induce complete membrane disruption and processed as above to measure the final electrical conductivity of the solution $\left(\mathrm{EC}_{\mathrm{f}}\right)$. The relative electrolyte leakage $(\mathrm{REL})$ was calculated as: $\left(\mathrm{EC}_{\mathrm{i}} / \mathrm{EC}_{\mathrm{f}}\right) \times 100$.

\subsection{Structural Traits and Biomass Allocation}

Watered samples used for estimating RWC values were also measured for estimating leaf dry matter content, (LDMC) as well as stem (SDMC) and the root (RDMC) dry matter content (as analogue of LDMC). LDMC, SDMC and RDM values were estimated by the ratio between leaf, stem or root dry weight and the corresponding turgid weight. Moreover, stem and leaf dry weight ratio and root and shoot dry weight ratio were also calculated.

Root, stem and leaves dry biomass was estimated by oven drying samples for $3 \mathrm{~d}$ at $70^{\circ} \mathrm{C}$.

\subsection{Plant Hydraulic Conductance Measurements by EFM}

Plant hydraulic conductance $\left(\mathrm{K}_{\text {plant }}\right)$ values were measured in planta by the Evaporative Flux Method, EFM (35) as:

$$
\mathrm{K}_{\text {plant }}: \mathrm{E}_{\mathrm{L}} /\left(\Psi_{\text {soil }}-\Psi_{\mathrm{L}}\right)
$$

where $\Psi_{\text {soil }}$ is the soil water potential estimated by a psycrometer (WP4, Decagon Devices, Pullman, WA, USA). All hydraulic conductance values were corrected to a temperature of $20{ }^{\circ} \mathrm{C}$ to consider changes in water viscosity.

Hydraulic measurements were estimated in at least 6 samples per species (i.e., $S$. ceratophylloides and S. officinalis) and per treatment.

The EFM is expected for providing relative values of hydraulic conductance due to its intrinsic limit in estimating the transpiration of the whole plant. Nevertheless, different studies have reported comparable data between EFM and other hydraulic measurements [59-61]. Moreover, the method is considered suitable for comparing values when recorded in similar environmental conditions. Thus, in order to perform reliable hydraulic measurements, the water stress treatment was not imposed the same day in all samples. This experimental procedure allowed us to perform measurements on the same day (and then similar environmental condition) on at least $3 \mathrm{~W}, 3 \mathrm{~S}$ and 3 Rec samples per species and treatment, thus avoiding, as possible, differences in transpiration rate values induced by different boundary layer resistance. Nevertheless, temperature as well as RH values (and then VPD) were similar during the entire experimental period.

\subsection{Statistical Analysis}

Data were analyzed with the SigmaStat 12.0 (SPSS, Inc., Chicago, IL, USA) statistics package. To test leaf structural traits, plant biomass and water storage traits, a $t$ test was performed. To test the differences among species (S, i.e., Sc and So) and the effects of the irrigation treatment (T, i.e., well-watered, $\mathrm{W}$, water-stressed, $\mathrm{S}$ and re-irrigated, Rec, samples) on $g_{L}, E_{L}, A_{n}, W U E, \Psi_{L}, K_{\text {plant }}, R W C$, PLRC and REL a two-way ANOVA test was performed. When the difference was significant, a post hoc Holm-Sidak test was conducted. The significance of correlations was tested using the Pearson product-moment coefficient. Significance was evaluated in all cases at $p<0.05$. Relationships between $K_{\text {plant }}$ and leaf, stem, and root RWC, PLRC and REL values and associate 95\% confidence intervals (C.I.s) were assessed in order to obtain species-specific and plant organ specific thresholds. Specifically, values of RWC $\left(\right.$ RWC $_{50 \mathrm{~K}}$ and $\left.\mathrm{RWC}_{80 \mathrm{~K}}\right), \mathrm{PLRC}\left(\mathrm{PLRC}_{50 \mathrm{~K}}, \mathrm{PLRC}_{80 \mathrm{~K}}\right)$ and REL (REL $50 \mathrm{~K}$ and REL $80 \mathrm{~K}$ ) corresponding to $50 \%$ and $80 \%$ loss of $\mathrm{K}_{\text {plant }}$ were estimated for each plant organ in $S c$ and $S o$. 


\section{Conclusions}

Results recorded in the present study highlight as root plays a key role in plant drought resilience in the two measured Salvia species. Large biomass allocation into the root system likely allows to higher accumulation of reserves for sustaining post-drought recovery. Further studies monitoring leaf, stem and root water content and loss in cell rehydration capability can provide important insights, enabling a comprehensive understanding of drought resistance strategies of Mediterranean species, and more accurate prediction of their fate in response to global warming.

Supplementary Materials: The following are available online at https:/ /www.mdpi.com/article/10 .3390/plants10091888/s1, Figure S1: $\mathrm{g}_{\mathrm{L}}$ and $\Psi_{\mathrm{L}}$ relationships in Sc versus So samples; Table S1: RWC, PLRC and REL thresholds of drought-driven $\mathrm{K}_{\text {plant }}$ decline of $S c$ and $S o$.

Author Contributions: Conceptualization, P.T. and E.A.; methodology, E.A., M.A. and P.T.; validation, E.A., M.A. and P.T.; formal analysis, E.A. and P.T.; investigation, E.A., M.A. and P.T.; resources, P.T.; data curation, M.A.; writing—original draft preparation, E.A.; writing—review and editing, P.T.; visualization, E.A., M.A. and P.T.; supervision, P.T.; project administration, P.T.; funding acquisition, P.T. All authors have read and agreed to the published version of the manuscript.

Funding: This research was funded by by Ministero dell'Istruzione, dell'Università e della Ricerca, Grant/Award Number: FFABR 2017.

Institutional Review Board Statement: Not applicable.

Informed Consent Statement: Not applicable.

Data Availability Statement: Not applicable.

Acknowledgments: We are grateful to Orto Botanico P. Castelli, University of Messina, Italy, for kindly providing plant material.

Conflicts of Interest: The authors declare no conflict of interest. The funders had no role in the design of the study; in the collection, analyses, or interpretation of data; in the writing of the manuscript; or in the decision to publish the results.

\section{References}

1. Allen, C.D.; Macalady, A.K.; Chenchouni, H.; Bachelet, D.; McDowell, N.; Vennetier, M.; Kitzberger, T.; Rigling, A.; Breshears, D.D.; Hogg, E.H.; et al. A global overview of drought and heat-induced tree mortality reveals emerging climate change risks for forests. For. Ecol. Manag. 2010, 259, 660-684. [CrossRef]

2. Carnicer, J.; Coll, M.; Ninyerola, M.; Pons, X.; Sánchez, G.; Peñuelas, J. Widespread crown condition decline, food web disruption, and amplified tree mortality with increased climate change-type drought. Proc. Natl. Acad. Sci. USA 2011, 108, 1474-1478. [CrossRef] [PubMed]

3. Menezes-Silva, P.E.; Loram-Lourenço, L.; Alves, R.D.F.B.; Sousa, L.F.; Almeida, S.E.D.S.; Farnese, F.S. Different ways to die in a changing world: Consequences of climate change for tree species performance and survival through an ecophysiological perspective. Ecol. Evol. 2019, 9, 11979-11999. [CrossRef] [PubMed]

4. Giorgi, F. Climate change hot-spots. Geophys. Res. Lett. 2006, 33, L08707. [CrossRef]

5. Mariotti, A.; Pan, Y.; Zeng, N.; Alessandri, A. Long-term climate change in the Mediterranean region in the midst of decadal variability. Clim. Dyn. 2015, 44, 1337-1456. [CrossRef]

6. Drobinski, P.; Da Silva, N.; Bastin, S.; Mailler, S.; Muller, C.; Ahrens, B.; Christensen, O.B.; Lionello, P. How warmer and drier will the Mediterranean region be at the end of the twenty-first century? Reg. Environ. Chang. 2020, 20, 78. [CrossRef]

7. Cramer, W.; Guiot, J.; Fader, M.; Garrabou, J.; Gattuso, J.P.; Iglesias, A.; Lange, M.A.; Lionello, P.; Llasat, M.C.; Paz, S.; et al. Climate change and interconnected risks to sustainable development in the Mediterranean. Nat. Clim. Chang. 2018, 8, 972-980. [CrossRef]

8. Lionello, P.; Scarascia, L. The relation between climate change in the Mediterranean region and global warming. Reg. Environ. Chang. 2018, 12, 1481-1493. [CrossRef]

9. Peñuelas, J.; Sardans, J.; Filella, I.; Estiarte, M.; Llusìa, J.; Ogaya, R.; Carnicer, J.; Bartrons, M.; Rivas-Ubach, A.; Grau, O.; et al Assessment of the impacts of climate change on Mediterranean terrestrial ecosystems based on data from field experiments and long-term monitored field gradients in Catalonia. Environ. Exp. Bot. 2018, 152, 49-59. [CrossRef]

10. Juhlke, T.R.; Van Geldern, R.; Barth, J.A.C.; Bendix, J.; Bräuning, A.; Garel, E.; Häusser, M.; Huneau, F.; Knerr, I.; Santoni, S.; et al. Temporal offset between precipitation and water uptake of Mediterranean pine trees varies with elevation and season. Sci. Total Environ. 2021, 755, 142539. [CrossRef] 
11. Underwood, E.C.; Viers, J.H.; Klausmeyer, K.R.; Cox, R.L.; Shaw, M.R. Threats and biodiversity in the Mediterranean biome. Divers. Distrib. 2009, 15, 188-197. [CrossRef]

12. Ubran, M.C. Accelerating extinction risk from climate change. Science 2015, 348, 571-573.

13. Molina-Venegas, R.; Ramos-Gutiérrez, I.; Moreno-Saiz, J.C. Phylogenetic patterns of extinction risk in the endemic flora of a mediterranean hotspot as a guiding tool for preemptive conservation actions. Front. Ecol. Evol. 2020, 8, 571587. [CrossRef]

14. Rundel, P.W.; Arroyo, M.T.K.; Cowling, R.M.; Keeley, J.E.; Lamont, B.B.; Vargas, P. Mediterraneanbiomes: Evolution of their vegetation, floras, and climate. Ann. Rev. Ecol. Evol. Syst. 2016, 47, 383-407. [CrossRef]

15. Molina-Venegas, R.; Aparicio, A.; Lavergne, S.; Arroyo, J. Climatic and topographical correlates of plant palaeo- and neoendemism in a Mediterranean biodiversity hotspot. Ann. Bot. 2017, 119, 229-238. [CrossRef] [PubMed]

16. Vilagrosa, A.; Bellot, J.; Gil-Pelegrin, E. Cavitation, stomatal conductance, and leaf die-back in seedlings of two co-occuring Mediterranean shrubs during an intense drought. J. Exp. Bot. 2003, 390, 2015-2024. [CrossRef] [PubMed]

17. Vilagrosa, A.; Hernández, E.I.; Luis, V.C.; Cochard, H.; Pausas, J.G. Physiological differences explain the co-existence of different regeneration strategies in Mediterranean ecosystems. New Phytol. 2014, 201, 1277-1288. [CrossRef]

18. Hernandéz, E.I.; Vilagrosa, A.; Pausas, J.G.; Bellot, J. Morphological traits and water use strategies in seedlings of Mediterranean coexisting species. Plant Ecol. 2010, 207, 233-244. [CrossRef]

19. West, A.G.; Dawson, T.E.; February, E.C.; Midgley, G.F.; Bond, W.J.; Aston, T.L. Diverse functional responses to drought in a Mediterranean-type shrubland in South Africa. New Phytol. 2012, 195, 396-407. [CrossRef] [PubMed]

20. Nardini, A.; Lo Gullo, M.A.; Trifilò, P.; Salleo, S. The challenge of the Mediterranean climate to plant hydraulics: Responses and adaptations. Environ. Exp. Bot. 2014, 103, 68-79. [CrossRef]

21. Gazol, A.; Sanguesa-Barreda, G.; Granda, E.; Camarero, J.J. Tracking the impact of drought on functionally different woody plants in a Mediterranean scrubland ecosystem. Plant Ecol. 2017, 218, 1009-1020. [CrossRef]

22. McDowell, N.G.; Brodribb, T.J.; Nardini, A. Hydraulics in the 21st century. New Phytol. 2019, 224, 537-542. [CrossRef]

23. Anderegg, W.R.L.; Klein, T.; Bartlett, M.; Sack, L.; Pellegrini, A.F.A.; Choat, B.; Jansen, S. Meta-analysis reveals that hydraulic traits explain cross-species patterns of drought-induced tree mortality across the globe. Proc. Natl. Acad. Sci. USA 2016, 113, 5024-5029. [CrossRef] [PubMed]

24. Choat, B.; Brodribb, T.J.; Brodersen, C.R.; Duursuma, R.A.; López, R.; Medlyn, B.E. Triggers of tree mortality under drought. Nature 2018, 558, 531-539. [CrossRef] [PubMed]

25. Klein, T.; Zeppel, M.J.B.; Anderegg, W.R.L.; Bloemen, J.; De Kauwe, M.G.; Hudson, P.; Ruehr, N.K.; Powell, T.L.; von Arx, G.; Nardini, A. Xylem embolism refilling and resilience against drought-induced mortality in woody plants: Processes and trade-offs Ecol. Res. 2018, 33, 839-855. [CrossRef]

26. Martinez-Vilalta, J.; Anderegg, W.R.L.; Sapes, G.; Sala, A. Greater focus on water pools may improve our ability to understand and anticipate drought-induced mortality in plants. New Phytol. 2019, 223, 22-32. [CrossRef]

27. Sapes, G.; Roskilly, B.; Dobrowski, S.; Maneta, M.; Anderegg, W.R.L.; Martinez-Vilalta, J.; Sala, A. Plant water content integrates hydraulics and carbon depletion to predict drought-induced seedling mortality. Tree Physiol. 2019, 39, 1300-1312. [CrossRef]

28. Sapes, G.; Sala, A. Relative water content consistently predicts drought mortality risk in seedling populations with different morphology, physiology, and times to death. Plant. Cell Environ. 2021, in press. [CrossRef]

29. Rosner, S.; Heinze, B.; Savi, T.; Dalla-Salda, G. Prediction of hydraulic conductivity loss from relative water loss: New insights into water storage of tree stems and branches. Physiol. Plant. 2019, 165, 843-854. [CrossRef]

30. Mantova, M.; Menezes-Silva, P.E.; Badel, E.; Cochard, H.; Torres-Ruiz, J.M. The interplay of hydraulic failure and cell vitality explains tree capacity to recover from drought. Physiol. Plant. 2021, 172, 247-257. [CrossRef]

31. Crisafulli, A.; Cannavò, S.; Maiorca, G.; Musarella, C.M.; Signorino, G.; Spampinato, G. Aggiornamenti floristici per la Calabria. Inf. Bot. Ital. 2010, 42, 437-448.

32. Spampinato, G.; Crisafulli, A.; Marino, A.; Signorino, G. Salvia ceratophylloides Ard. Inf. Bot. Ital. 2011, 43, $381-458$.

33. Vescio, R.; Abenavoli, M.R.; Araniti, F.; Musarella, C.M.; Sofo, A.; Laface, V.L.A.; Spampinato, G.; Sorgonà, A. The assessment and the within-plant variation of the morpho-physiological traits and VOCs profile in endemic and rare Salvia ceratophylloides Ard (Lamiaceae). Plants 2021, 10, 474. [CrossRef]

34. Pignatti, S. Flora d'Italia; Edagricole: Bologna, Italy, 2002.

35. Raimondo, F.; Trifilò, P.; Lo Gullo, M.A.; Andri, S.; Savi, T.; Nardini, A. Plant performance on Mediterranean green roofs: Interaction of species-specific hydraulic strategies and substrate water relations. AoB Plants 2015, 7, plv007. [CrossRef]

36. Savi, T.; Marin, M.; Luglio, J.; Petruzzellis, F.; Mayr, S.; Nardini, A. Leaf hydraulic vulnerability protects stem functionality under drought stress in Salvia officinalis. Funct. Plant Biol. 2016, 43, 370-379. [CrossRef] [PubMed]

37. Blackman, C.J.; Gleason, S.M.; Chang, Y.; Cook, A.M.; Laws, C.; Westoby, M. Leaf hydraulic vulnerability to drought is linked to site water availability across a broad range of species and climates. Ann. Bot. 2014, 114, 435-440. [CrossRef] [PubMed]

38. Nardini, A.; Luglio, J. Leaf hydraulic capacity and drought vulnerability: Possible trade-offs and correlations with climate across three major biomes. Funct. Ecol. 2014, 28, 810-818. [CrossRef]

39. Fang, J.; Lutz, J.A.; Wang, L.; Shugart, H.H.; Yan, X. Using climate-driven leaf phenology and growth to improve predictions of gross primary productivity in North American forests. Glob. Chang. Biol. 2020, 26, 6974-6988. [CrossRef] [PubMed]

40. Abate, E.; Nardini, A.; Petruzzellis, F.; Trifilò, P. Too dry to survive: Leaf hydraulic failure in two Salvia species can be predicted on the basis of water content. Plant Physiol. Biochem. 2021, 166, 215-224. [CrossRef] 
41. Wright, I.J.; Reich, P.B.; Westoby, M.; Ackerly, D.D.; Baruch, Z.; Bongers, F.; Cavender-Bares, J.; Chapin, T.; Cornelissen, J.H.; Diemer, M.; et al. The worldwide leaf economics spectrum. Nature 2004, 428, 821-827. [CrossRef]

42. Brouillette, L.C.; Mason, C.M.; Shirk, R.Y.; Donovan, L.A. Adaptive differentiation of traits related to resource use in a desert annual along a resource gradient. New Phytol. 2014, 201, 1316-1327. [CrossRef]

43. Poorter, H.; Niinemets, U.; Poorter, L.; Wright, J.J.; Villar, R. Causes and consequences of variation in leaf massa area (LMA): A meta-analysis. New Phytol. 2009, 182, 565-588. [CrossRef]

44. Forner, A.; Valladeres, F.; Aranda, I. Mediterranean trees coping with severe drought: Avoidance might not be safe. Environ. Exp. Bot. 2014, 155, 529-540. [CrossRef]

45. North, G.B.; Nobel, P.S. Changes in hydraulic conductivity and anatomy caused by drying and rewetting roots of Agave deserti. Am. J. Bot. 1991, 78, 906-915. [CrossRef]

46. North, G.B.; Nobel, P.S. Radial hydraulic conductivity of individual root yissues of Opuntia ficus-indica (L.) Miller as soil moisture varies. Ann. Bot. 1996, 77, 133-142. [CrossRef]

47. Trifilò, P.; Raimondo, F.; Nardini, A.; Lo Gullo, M.A.; Salleo, S. Drought resistance of Ailanthus altissima: Root hydraulics and water relations. Tree Physiol. 2004, 24, 107-114. [CrossRef] [PubMed]

48. Cuneo, I.F.; Barrios-Masias, F.; Knipfer, T.; Uretsky, J.; Reyes, C.; Lenain, P.; Brodersen, C.R.; Walker, M.A.; McElrone, A.J. Differences in grapevine rootstock sensitivity and recovery from drought are linked to fine root cortical lacunae and root tip function. New Phytol. 2021, 229, 272-283. [CrossRef] [PubMed]

49. Nobel, P.S.; Sanderson, J. Rectifier-like activities of roots of two desert succulents. J. Exp. Bot. 1984, 35, 727-737. [CrossRef]

50. Padilla, F.M.; Miranda, J.D.; Jorquera, M.J.; Pugnaire, F.I. Variability in amount and frequency of water supply affects roots but not growth of arid shrubs. Plant Ecol. 2009, 204, 261-270. [CrossRef]

51. Markesteijn, L.; Poorter, L. Seedling root morphology and biomass allocation of 62 tropical tree species in relation to droughtand shade-tolerance. J. Ecol. 2009, 97, 311-325. [CrossRef]

52. Lopez_Iglesis, B.; Villar, R.; Poorter, L. Functional traits predict drought performance and distribution of Mediterranean woody species. Acta Oecol. 2014, 56, 10-18. [CrossRef]

53. Creek, D.; Blackmann, C.J.; Brodribb, T.J.; Choat, B. Coordination between leaf, stem, and root hydraulics and gas exchange in three arid-zone angiosperms during severe drought and recovery. Plant Cell Environ. 2018, 12, 2869-2881. [CrossRef] [PubMed]

54. Rodriguez-Domiguez, C.M.; Brodribb, T.J. Declining root water transport drives stomatal closure in olive under moderate water stress. New Phytol. 2019, 225, 126-134. [CrossRef] [PubMed]

55. Bourbia, I.; Pritzkow, C.; Brodribb, T.J. Herb and conifer roots show similar high sensitivity to water deficit. Plant Physiol. 2021, 186, 1908-1918. [CrossRef]

56. Weigelt, A.; Mommer, L.; Andraczek, K.; Iversen, C.M.; Bergmann, J.; Bruelheide, H.; Fan, Y.; Freschet, G.T.; Guerrero-Ramírez, N.R.; Kattge, J.; et al. An integrated framework of plant form and function: The belowground perspective. New Phytol. 2021, 232, 42-59. [CrossRef]

57. Pivovaroff, A.L.; Sack, L.; Santiago, L.S. Coordination of stem and leaf hydraulic conductance in southern California shrubs: A test of the hydraulic segmentation hypothesis. New Phytol. 2014, 203, 842-850. [CrossRef]

58. Trifilò, P.; Petruzzellis, F.; Abate, E.; Nardini, A. The extra-vascular water pathway regulates dynamic leaf hydraulic decline and recovery in Populus nigra. Physiol. Plant. 2021, 172, 29-40. [CrossRef]

59. Tsuda, M.; Tyree, M.T. Plant hydraulic conductance measured by the high pressure flow meter in crop plants. J. Exp. Bot. 2000, 51, 823-828. [CrossRef]

60. Trifilò, P.; Nardini, A.; Raimondo, F.; Lo Gullo, M.A.; Salleo, S. Ion-mediated compensation for drought-induced loss of xylem hydraulic conductivity in field-growing plants of Laurus nobilis. Funct. Plant Biol. 2010, 38, 606-613. [CrossRef]

61. Aranda, I.; Gil, L.; Pardos, J.A. Seasonal changes in apparent hydraulic conductance and their implications for water use of European beech (Fagus sylvatica L.) and sessile oak [Quercus petraea (Matt.) Liebl] in South Europe. Plant Ecol. 2005, 179, 155-167. [CrossRef] 